\title{
FINDING THE OPTIMUM LEVEL OF TAXES IN SOUTH AFRICA: A BALANCED BUDGET APPROACH
}

\author{
N.J. Schoeman ${ }^{1 *}$ and Y. van Heerden ${ }^{2}$ \\ ${ }^{1,2}$ Department of Economics \\ University of Pretoria, South Africa \\ ${ }^{1 *}$ niek.schoeman@up.ac.za, ${ }^{2}$ yolande.jordaan@up.ac.za
}

\begin{abstract}
This article is primarily concerned with assessing the optimum rate of government intervention by means of tax revenue policies that would facilitate the full growth potential of the South African economy, using time series data for the period 1960 to 2007. In the analysis a balanced budget is assumed, which means that the level of expenditure is set equal to tax collection with no provision for borrowing. The results indicate that the actual average tax burden far exceeds its optimum level, and that the authorities will have to consider adjusting tax policy accordingly in order to improve the growth performance of the economy.
\end{abstract}

\section{OPSOMMING}

Hierdie artikel het primêr ten doel die assessering van die optimale koers van belastinginkomstebeleid wat die volle groeipotensiaal van die Suid-Afrikaanse ekonomie sal ondersteun, deur gebruik te maak van tydreeksdata oor die periode 1960 to 2007. In die analise is 'n gebalanseerde begroting aanvaar, wat beteken dat die vlak van uitgawes gelyk gestel is aan die vlak van belastinginvorderings, en geen voorsiening word gemaak vir lenings nie. Die resultate dui daarop dat die werklike gemiddelde belastingdruk die optimale vlak aansienlik oorskry, en dat die owerheid moet oorweeg om die belastingbeleid dienooreenkomstig aan te pas om die groeipotentiaal van die ekonomie te verhoog.

\footnotetext{
${ }^{1 *}$ Corresponding author

${ }^{2}$ The author was enrolled for an MCom (Econometrics) degree in the Department of Economics, University of Pretoria.
} 


\section{INTRODUCTION}

As in many other countries, the growth rates of taxes and government expenditure in South Africa tend to exceed economic growth, and the country is noted for its relatively high levels of taxation. However, in a developing country such as South Africa, the merit of this phenomenon should be weighed against the growing needs on the expenditure side (Koch et al. [29]).

In this study an attempt is made to determine the optimum average rate for economic growth in South Africa, by using a balanced budget approach. A Cobb-Douglas type production function is used with two sectors: government and non-government. The government sector provides goods and services from the production process financed from tax revenue - i.e. $g=\tau(g d p)$ ( $\mathrm{a}$ balanced budget). Production by the non-government sector is equal to the inverse of the government's share of national output $(1-\tau) \operatorname{gdp}$. Casual analysis shows that, similar to findings in other studies, the impact of government intervention is positive (when $\tau \leq$ optimum level) or negative (when $\tau>$ optimum level).

Thus a negative relationship seems to exist between the $\frac{\operatorname{tax}}{\operatorname{gdp}}$ ratio $(\tau)$ and the economic growth rate (Black et al. [7]).

Government expenditure comprises public goods such as education, social services, security, and health, and in a balanced budget context sufficient funding is required to provide these services to the public. Clearly, the secret is to find the optimum level of taxes in order to optimise economic growth without disturbing the morale of the general public (Rosen [44]).

The notion is that with this optimum tax level, economic growth should be maximised, employment should grow, and tax evasion should be minimised. However, a tax rate beyond this optimum level has a negative effect on economic growth, also impacting negatively on the economic behaviour of the tax-paying public. For example, tax rates that are too high result in lower productivity and savings (Black et al. [7]). Such a change in behaviour is often caused by a double tax effect since, firstly, tax payers have to pay their taxes; but, secondly, they also experience a decrease in their standard of living because of the concomitant lower growth rates (Scully [47]).

Disposable income declines, and with that, consumption and investment decline too, causing substitution of leisure for labour. This result in a loss not only in hours worked, but probably also in labour productivity (Feldstein [23]). The decline in savings (especially household savings) in South Africa over the past decade is often mentioned as the result of tax rates that are too high.

In order to estimate an optimum average tax rate that would optimise economic growth, expenditure should also be optimised by improving its efficiency. For example, appointing more teachers would be a 'quantity' solution to improving education, but spending more on the current teachers' skills would probably contribute more to improving education - and the budget would be spent more effectively (Hood et al. [26]).

The layout of the rest of the paper is as follows: Section 2 contains a review of the relevant literature. Section 3 analyses government expenditure and tax ratios in South Africa, while the analytical framework is discussed in Section 4 and the data used in Section 5 . The empirical results of the analysis are presented in Section 6, and Section 7 concludes with some policy recommendations.

\section{LITERATURE REVIEW}

In a paper by Chao et al. [15], the relationship between economic growth and the level of government expenditure in Canada is illustrated (Figure 1 below). The GDP growth rate is 
shown on the vertical axis; government expenditure/total taxes as a percentage of GDP are on the horizontal axis. At a zero level of government expenditure (government is absent), the growth rate is $g_{A}$ (no rule of law exists, i.e. a state of chaos). At this zero rate of government expenditure, output is at a low level with little incentive to save and invest. With increasing expenditure on (for example) national defence, a legal system, and education, economies of scale become evident. The BC line in the curve shows that the proportional increase in government expenditure is less than the proportional increase in economic growth. Eventually, the marginal rate of return on such additional government expenditure reaches level zero at point $C$. Thus the optimum level of government expenditure as a percentage of GDP is reached at $\tau$ *, after which the marginal return on such expenditure in terms of value added becomes negative.

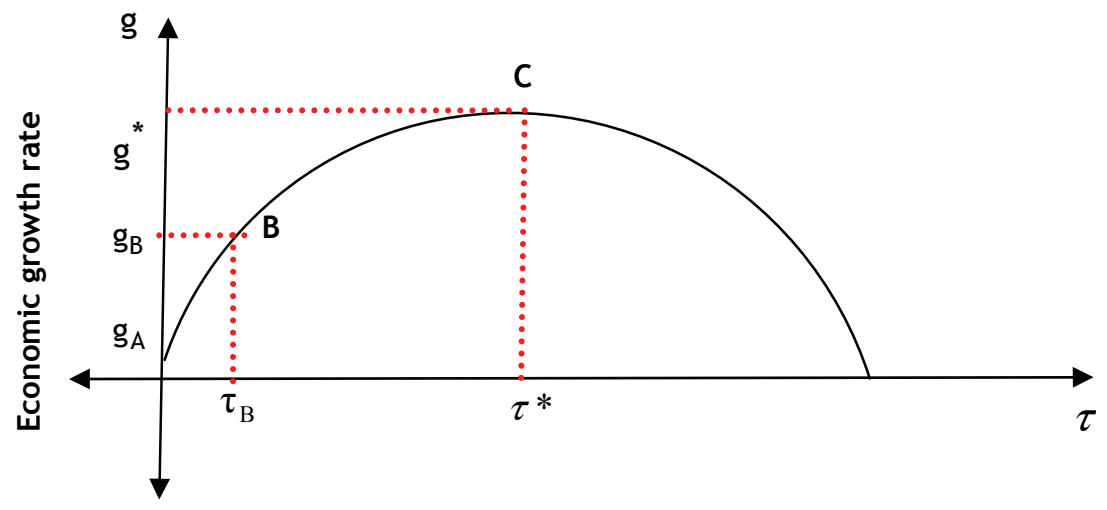

Government expenditure/Total taxes as a percentage of GDP

Figure 1: The relationship between economic growth and public expenditure/taxes Source: Chao et al. [15]

The Ricardian equivalence theory suggests that the current generation might be undertaxed if government borrows (debt financing) instead of only levying taxes to finance government expenditure. The notion is that rising public debt will result in higher future taxes. Therefore, debt financing only spreads the tax burden over more than one generation. Should taxes be used to finance expenditure instead, the current generation would rather bear the burden. Thus, the Ricardian equivalence theorem holds that it is indifferent whether tax or debt financing is used, since the current generation would increase their private savings by reducing their private consumption, realising that such loans would have to be repaid in future from tax revenue (Black et al. [7]). The impact of this is that the multiplier affects are neutralised and the stimulation of the economy by public intervention is largely constrained.

Schoeman [46] refers to Barro's provocative hypothesis that government funding by means of taxes or new debt might be irrelevant, since private individuals could discount the intergenerational effects of government debt policy by spending less (saving more). In a study where the public sector is incorporated into a simple, constant-returns endogenousgrowth model, Barro [4] points out that a potentially positive linkage exists between government expenditure and economic growth, but that the size of government does matter. When government is relatively small, a positive relationship exists between government expenditure as a percentage of GDP and the growth rate; but when government grows relatively larger, this relationship becomes negative.

Mitchell [38] finds evidence that economic performance is sensitive to the level of taxation. Therefore, a lower tax rate enhances the level of compliance: more people pay their taxes. Mitchell concludes that lowering tax rates improves investment, savings, and incentives to 
work, and also enhances the immediate and long term development of small business and entrepreneurship. However, higher tax rates lower the price of leisure and thereby reduce the levels of saving, investment, and labour productivity, probably resulting in lower levels of production. Mitchell states that capital supply mainly originates from higher income tax payers who are more sensitive to the level of tax rates. By implication, a lowering of marginal tax rates would induce higher savings, thereby broadening the capital base and thus increasing the growth potential of the economy. The general notion seems to be that government expenditure on public goods (infrastructure, education, health, defence) improves the productivity of human and fixed capital, which in turn would increase economic growth and thereby raise individual living standards (Scully [47]). Such expenditure has to be financed, and the effect of taxation on economic growth depends on the magnitude of this government expenditure.

In a paper on the size of government, Clemens et al. [16] support the Grossman hypothesis (1988), namely, that a negative relationship exists between government expenditure and economic growth. They also cite a study by Vedder et al. [52], who find that a decrease in government expenditure would be growth-enhancing, and estimate that the growth of the United States economy would be optimised if government expenditure as a percentage of GDP were fixed at around $17.5 \%$ of GDP. Clemens et al. [16] also cite a study by Peden et al. [42], who set the estimated optimal level of government expenditure as a percentage of GDP at $17 \%$ for the US, warning that any increase beyond this optimal point would dampen economic growth. The studies referred to seem to concur that an inverse relationship exists between the level of government expenditure and economic growth, at least when government expenditure has exceeded a certain critical level.

This inverse relationship between government expenditure and economic growth is also confirmed by Pevcin [41], who did a panel regression on 12 European countries (Austria, Belgium, Denmark, Finland, France, Germany, Ireland, Italy, The Netherlands, Norway, Sweden, and the United Kingdom) for the period 1951 to 1995 . In this study the average

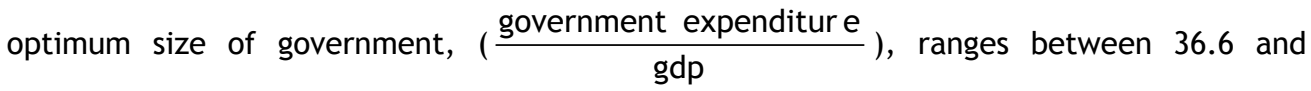
42.1\%. Pevcin concludes that countries with a higher level of government expenditure experience lower rates of economic growth.

Scully [47] also elaborates on the relationship between the level of government expenditure/taxes and economic growth. He states that government expenditure grows to a certain optimum point, after which productivity and economic growth are reduced. He finds that tax rates affect not only government revenue but also economic efficiency. High tax rates divert resources from the private sector, encourage tax avoidance and evasion, and channel resources into a less productive 'shadow' (or informal) economy in order to escape the high taxes.

According to Scully, countries that increase government revenue at the expense of economic growth expose their taxpayers to some form of double taxation. The first tax is paid according to the tax jurisdiction, and the second 'tax' is a lowering of their standard of living, caused by lower economic growth. The study concludes that, after a 40 -year period of optimum levels of taxation, a country would enjoy more than three times as much economic growth.

Scully [ibid] estimates that the optimal level of federal, state, and local government expenditure/taxation for the US is around $19 \%$ to $23 \%$. The Scully model estimates a growthmaximising tax rate for the years 1927 to 1994 at an average $19.7 \%$ of GDP for New Zealand (Caragata [14]). Mackness [32] estimates the optimum size of the tax rate for Canada at about 20\% to 30\% of GDP. Mavrov [36] finds the optimum ratio for government expenditure as percentage of GDP in Bulgaria to be $21.4 \%$.

All of these studies find that the optimum tax rate is much lower than the actual tax rate in these countries. 
Mirrlees [37] suggests that government expenditure could be growth-enhancing or growthretarding, depending on its end use. The outcome is determined by the nature of the expenditure, as well as the way in which it is financed.

In the next section, government expenditure and revenue ratios in South Africa are analysed in order to test the relevance of the theories discussed.

\section{GOVERNMENT EXPENDITURE AND TAX RATIOS IN SOUTH AFRICA}

Tax reform in South Africa mainly resulted from the recommendations of three commissions: the Franzsen Commission (1968), the Margo Commission (1987), and the Katz Commission (1994). The main objectives of all three commissions were to reduce income tax ratios and shift the tax burden more towards expenditure taxes, expecting the shift to increase productivity and social welfare and, therefore, economic growth as well. Thus, during this period South Africa's tax system went through a number of reforms. During the 1980 s, the economy endured international sanctions that lead to a loss of international investment and the debt standstill. The Katz Commission was appointed at the time of South Africa's new political dispensation, when international trade sanctions were gradually lifted. As a determinant of the ideal level and size of government intervention, the Katz Commission [27] prioritised the poverty challenge.

In his 2002 speech on tax reform experience in South Africa since 1994, the Minister of Finance stated that the fiscal achievements were

"stabilisation of the tax burden at approximately $25 \%$ of GDP" and "a decline in government consumption expenditure as a percentage of GDP, from $20 \%$ in the mid-1990s to 18\% in 2001" (Budget Review [13]).

In June 1996 the government adopted a five-year macro-economic programme called Growth, Employment and Redistribution (hereinafter referred to as 'GEAR'). This programme's goal was to achieve sustained annual real GDP growth of $6 \%$ or more by the year 2000, with increased job opportunities and investment. The latter objectives were not achieved, but the growth rate increased from its negative base in 1990 to more than $4.1 \%$ in 2000, as shown in Table 1.

\begin{tabular}{|l|c|r|r|r|r|r|r|r|}
\hline \multicolumn{1}{|c|}{ Series } & Code & 1981 & 1984 & 1990 & 1995 & 2000 & 2004 & 2007 \\
\hline $\begin{array}{l}\text { Tax on individuals as a } \\
\text { percentage of total revenue }\end{array}$ & KBP4429J & 20.7 & 31.7 & 32.2 & 40.6 & 42.1 & 33.1 & 30.1 \\
\hline $\begin{array}{l}\text { Tax on companies as a } \\
\text { percentage of total revenue }\end{array}$ & KBP4430J & 34.5 & 22.9 & 22.6 & 13.1 & 16.0 & 23.2 & 29.4 \\
\hline $\begin{array}{l}\text { VAT as a percentage of total } \\
\text { revenue }\end{array}$ & KBP4431J & 13.6 & 23.3 & 24.4 & 26.0 & 25.0 & 28.3 & 27.2 \\
\hline $\begin{array}{l}\text { Tax revenue as a percentage } \\
\text { of GDP }\end{array}$ & KBP4433J & 20.2 & 20.9 & 24.7 & 22.2 & 22.5 & 23.5 & 26.9 \\
\hline $\begin{array}{l}\text { Expenditure as a percentage } \\
\text { of GDP }\end{array}$ & KBP4434J & 22.1 & 24.3 & 25.5 & 27.1 & 24.4 & 25.5 & 26.1 \\
\hline GDP growth & KBP6006Z & 5.4 & 5.1 & -0.3 & 3.1 & 4.1 & 4.8 & 5.1 \\
\hline
\end{tabular}

Table 1: Tax revenue, government expenditure and economic growth rates Source: SA Reserve Bank (various sources) [45]

Table 1 also indicates the change in the tax burden between 1981 and 2007. Personal income tax comprised $42 \%$ of total tax revenue in 2000 , but its share declined to $30 \%$ in 2007. Company tax was $16 \%$ in 2000 , but increased to $29.4 \%$ as a percentage of total revenue. Corporate and individual rates were significantly reduced after 1994 (Budget [10]). 
Figure 2 shows the real economic growth rate and real government spending as a percentage of GDP for the years from 1960 to 2007. The graph indicates that during the period 1960 to 1965 the economic growth rate had been relatively high, with relatively lower levels of government spending. After 1970, the level of government expenditure started to increase and stayed around an average of 26\% between 1985 and 2007. During the 1980s South Africa experienced high inflation rates and foreign disinvestment, and growth rates fluctuated, with a low growth rate of $-1.9 \%$ in 1983. After the introduction of a new political dispensation and tax reform in 1994, the growth rate began to increase, reaching $5.1 \%$ in 2007. This tendency is similar to the findings of Devarajan et al. [17], according to which governments in developing countries spend on average $26 \%$ of GDP.

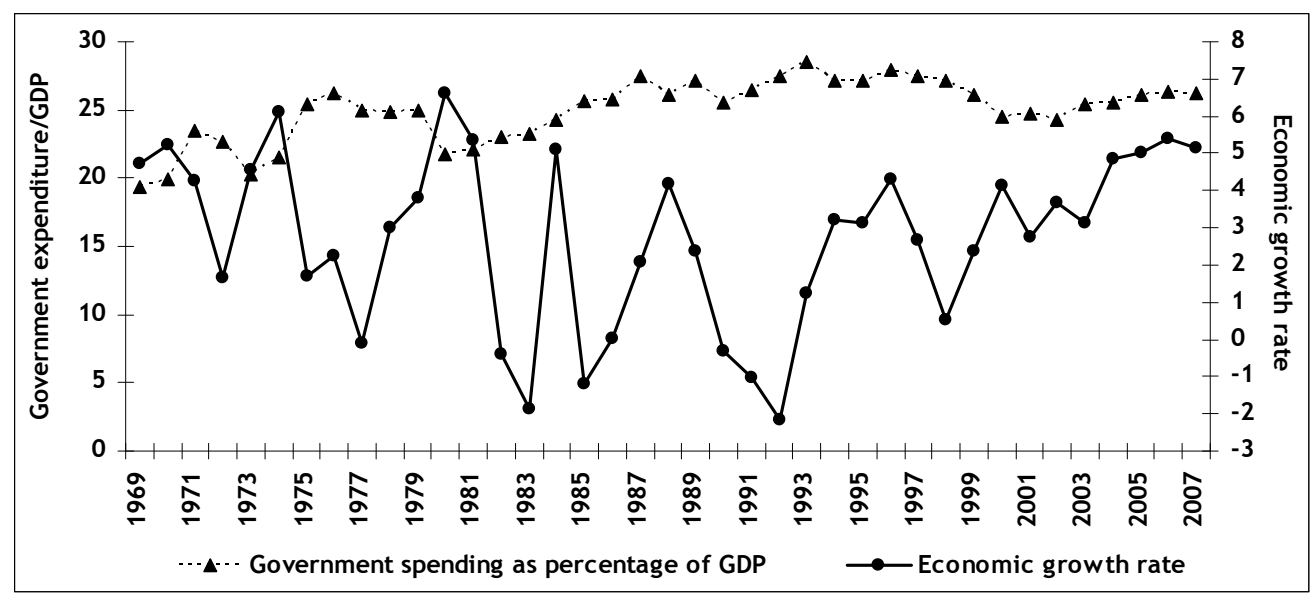

Figure 2: Government expenditure as percentage of GDP and the economic growth rate Source: South African Reserve Bank [45]

In Figure 3, the real economic growth rate is compared with the real government expenditure growth rate for the years from 1961 to 2007. It is interesting to note that the graph shows an inverse relationship between the economic growth rate and the change in government expenditure. For example, in the years 1966 to 1970 and 1976 to 1982, the inverse relationship is clear, perhaps indicating a margin of pro-cyclical expenditure by government.

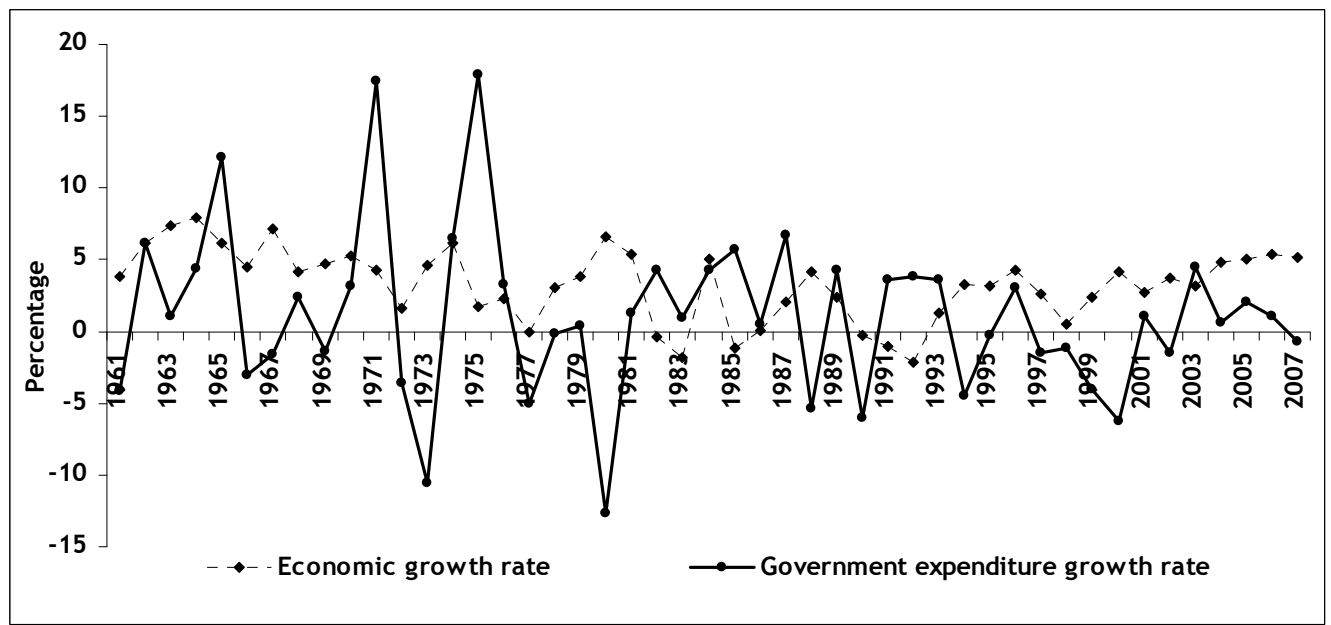

Figure 3: Change in government expenditure and the economic growth rate Source: South African Reserve Bank [45] 
In the next section an attempt will be made to quantify the optimal level of tax revenue for South Africa.

\section{ANALYTIC FRAMEWORK}

\subsection{Model specification}

The model used is based on a similar model by Scully [47], using a simple, constant-returns endogenous non-linear Cobb-Douglas production function. The rate of real economic growth is determined by the government and the private sector in the two sector model (government $\left(\mathrm{rg}_{\mathrm{t}}\right)$ and non-government $\left.\left((1-\tau) \mathrm{rgdp}_{\mathrm{t}}\right)\right)$. The model assumes a balanced budget, with government expenditure $=$ government revenue $\left(\mathrm{rg}_{t}=\tau\left(\operatorname{rgdp}_{t}\right)\right.$.

Thus the structure of the model is as follows:

$$
\mathrm{Y}_{\mathrm{t}}=\alpha\left(\mathrm{rg}_{\mathrm{t}}\right)^{\beta}\left((1-\tau) \operatorname{rgdp}_{\mathrm{t}}\right)^{\delta}
$$

with the growth rate:

$$
1+\mathrm{eg}_{\mathrm{t}}=\frac{\operatorname{rgdp}_{\mathrm{t}}}{\operatorname{rgdp}_{\mathrm{t}-1}}
$$

Substitute (1) in (2)

$$
1+\mathrm{eg}_{\mathrm{t}}=\frac{\operatorname{rgdp}_{\mathrm{t}}}{\operatorname{rgdp}_{\mathrm{t}-1}}=\alpha\left(\mathrm{rg}_{\mathrm{t}}\right)^{\beta}(1-\tau)^{\delta}\left(\operatorname{rgdp}_{\mathrm{t}}\right)^{\delta}\left(\mathrm{rgdp}_{\mathrm{t}-1}\right)^{-1}
$$

Where

$$
\begin{array}{ll}
\alpha & =\text { total factor productivity } \\
\operatorname{rgdp}_{t} & =\text { real gross domestic product (GDP) current period } \\
\operatorname{rgdp}_{t-1} & =\text { real gross domestic product (GDP) previous period } \\
\operatorname{rg}_{\mathrm{t}} & =\text { real government expenditure current period } \\
\mathrm{eg}_{\mathrm{t}} & =\text { economic growth rate current period } \\
\tau & =\text { tax ratio }
\end{array}
$$

In logarithm form:

$$
\ln \left(1+\mathrm{eg}_{\mathrm{t}}\right)=\ln \left(\frac{\mathrm{rgdp}_{\mathrm{t}}}{\mathrm{rgdp}_{\mathrm{t}-1}}\right)=\ln \alpha+\beta \ln \left(\mathrm{rg}_{\mathrm{t}}\right)+\delta \ln (1-\tau)+\delta \ln \left(\mathrm{rgdp}_{\mathrm{t}}\right)-\ln \left(\mathrm{rgdp}_{\mathrm{t}-1}\right)
$$

Next the economic growth rate is differentiated w.r.t. real government expenditure:

$$
\begin{array}{ll}
\frac{\partial \ln \left(1+e g_{t}\right)}{\partial r g_{t}}=\beta\left(\mathrm{rg}_{t}\right)^{-1} & >0 \\
\frac{\partial^{2} \ln \left(1+e g_{t}\right)}{\partial \operatorname{rg}_{t}^{2}}=-\beta\left(\mathrm{rg}_{\mathrm{t}}\right)^{-2} & <0
\end{array}
$$

Thus a positive relationship exists between real government expenditure and the growth rate, but at a diminishing rate. By increasing real government expenditure (holding 
productivity and employment constant), the growth rate will rise - but at a decreased rate when real government expenditure is lower.

Next the growth rate is differentiated w.r.t. tax rate $(\tau)$

$$
\begin{array}{ll}
\frac{\partial \ln \left(1+\mathrm{eg}_{\mathrm{t}}\right)}{\partial \tau}=-\delta(1-\tau)^{-1} & <0 \\
\frac{\partial^{2} \ln \left(1+\mathrm{eg}_{\mathrm{t}}\right)}{\partial \tau^{2}}=-\delta(1-\tau)^{-2} & <0
\end{array}
$$

The result is a negative relationship between economic growth and the tax rate, but at an increasing rate.

\subsection{Optimising the $\frac{\text { revenue }}{\text { gdp }}$ ratio that maximises economic growth}

Substitute $\mathrm{rg}=\tau(\mathrm{rgdp})$ (by definition) into (1) and simplify

$$
\begin{aligned}
& \operatorname{rgdp}_{\mathrm{t}}=\alpha\left(\tau\left(\operatorname{rgdp}_{\mathrm{t}}\right)\right)^{\beta}\left((1-\tau) \operatorname{rgdp}_{\mathrm{t}}\right) \\
& =\alpha(\tau){ }_{(1-\tau)} \delta\left(\operatorname{rgdp}_{\mathrm{t}}\right)
\end{aligned}
$$

Substitute (9) in (2):

$1+\mathrm{eg}_{\mathrm{t}}=\frac{\operatorname{rgdp}_{\mathrm{t}}}{\operatorname{rgdp}_{\mathrm{t}-1}}=\alpha(\tau){ }_{(1-\tau)}^{\beta}{ }_{\left(\operatorname{rgdp}_{\mathrm{t}}\right)}^{\beta+\delta}\left(\operatorname{rgdp}_{\mathrm{t}-1}\right)^{-1}$

Constant returns to scale $\beta+\delta=1$

Therefore:

$$
1+\mathrm{eg}_{\mathrm{t}}=\frac{\operatorname{rgdp}_{\mathrm{t}}}{\operatorname{rgdp}_{\mathrm{t}-1}}=\alpha\left(\tau^{\beta}(1-\tau) \delta\left(\operatorname{rgdp}_{\mathrm{t}}\right)\left(\operatorname{rgdp}_{\mathrm{t}-1}\right)^{-1}\right.
$$

The logarithm form of (11):

$$
\ln \left(1+\mathrm{eg}_{\mathrm{t}}\right)=\ln \alpha+\beta \ln \tau+\delta \ln (1-\tau)+\ln \left(\operatorname{rgdp}_{\mathrm{t}}\right)-\ln \left(\operatorname{rgdp}_{\mathrm{t}-1}\right)
$$

Differentiate (12) w.r.t. tax:

$$
\begin{aligned}
& \frac{\partial \ln \left(1+\mathrm{eg}_{\mathrm{t}}\right)}{\partial \tau}=\beta \alpha \tau^{-1}+\left[\delta(1-\tau)^{-1}(-1)\right]=0 \\
& \frac{\beta}{\tau}=\frac{\delta}{1-\tau} \\
& \frac{1-\tau}{\tau}=\frac{\delta}{\beta} \\
& \frac{1}{\tau}-1=\frac{\delta}{\beta} \\
& \frac{1}{\tau}=\frac{\beta}{\beta}+\frac{\delta}{\beta}
\end{aligned}
$$

Thus, the optimum tax rate that maximises growth $=\tau^{*}=\frac{\beta}{\beta+\delta}$ 


\section{EMPIRICAL FRAMEWORK}

\subsection{The data}

The parameters used in the model were estimated using annual time series data for the period 1960 to 2007 from the South African Reserve Bank (www.resbank.co.za). Detailed descriptions of the data are provided in Table 2. Ordinary Least Square Regression procedure is used to estimate the model. All data retrieved and used in the model is at current (nominal) prices and transformed to real values by using the CPI index.

\begin{tabular}{|c|c|c|c|}
\hline Series & $\begin{array}{l}\text { Abbre- } \\
\text { viation }\end{array}$ & Description & Transformation used \\
\hline KBP7032J & cpi & Consumer Price Index & $\begin{array}{l}\text { Yearly index, } \\
\text { Base year } 2000=100\end{array}$ \\
\hline KBP6006J & Y or gdp & Gross domestic product at market prices & Yearly, current prices \\
\hline KBP6008J & consg & $\begin{array}{l}\text { Final consumption expenditure: } \\
\text { general government }\end{array}$ & Yearly, current prices \\
\hline KBP6180J & capt & Gross capital formation & Yearly, current prices \\
\hline KBP6181J & capg & $\begin{array}{l}\text { Gross capital formation: } \\
\text { general government }\end{array}$ & Yearly, current prices \\
\hline KBP6007J & consng & $\begin{array}{l}\text { Final consumption expenditure by } \\
\text { households: total }\end{array}$ & Yearly \\
\hline KBP6013J & $x$ & Exports of goods \& services & Yearly \\
\hline KBP6014J & $z$ & Imports of goods \& services & Yearly \\
\hline Calculated & $z g$ & $\begin{array}{l}\text { Imports of goods \& services: } \\
\text { general government }\end{array}$ & $15 \%^{3 *} 50 \%$ * consg \\
\hline Calculated & zng & $\begin{array}{l}\text { Imports of goods \& services: } \\
\text { non-government }\end{array}$ & $z-z g$ \\
\hline Calculated & capng & $\begin{array}{l}\text { Gross capital formation: } \\
\text { non-government }\end{array}$ & capt - capg \\
\hline Calculated & g & Government expenditure & consg + capg -zg \\
\hline Calculated & ng & Non-government expenditure & consng + capng $+x$-zng \\
\hline Calculated & rgdp & Real gross domestic product & $(\mathrm{gdp} / \mathrm{cpi})^{*} 100$ \\
\hline Calculated & rg & Real government expenditure & $(\mathrm{g} / \mathrm{cpi})^{*} 100$ \\
\hline Calculated & rng & Real non-government expenditure & $(\mathrm{ng} / \mathrm{cpi}) * 100$ \\
\hline
\end{tabular}

Table 2: Data and description Source: SARB [45]

\footnotetext{
${ }^{3}$ The average of goods and services imported by government.
} 


\subsection{Estimation technique}

The appropriateness of the estimation techniques has to be valued against the availability of data. This study used 47 observations, and the number of methods that would be feasible was therefore limited. Differencing the series once, the ADF unit root test confirms stationarity of the series, (all series are I(0)).

Cointegration involves combining economic data series (although l(1)) through a linear combination into a single series, which is itself stationary. This process provides an indication of the variables that affect GDP in the long run. The Engle-Granger [19] two-step procedure and the error correction paradigms were adopted, despite its potential defects. This technique entails the determination of the long-term cointegration relationship through testing for stationarity of the residuals using Augmented Dickey-Fuller (ADF) tests. Any non-stationarity is then corrected for by means of a short-term error correction model (ECM).

The Engle-Granger two-step estimation technique has potential defects in the sense that it assumes that there is one cointegrating vector. It also carries an error made in the first step over to the second step of estimation. Since the number of variables $(n=4)$ in the model is greater than two, there can be more than one cointegrating relationship. The Johansen ${ }^{4}$ multivariate cointegration technique is more powerful than the Engle-Granger, but requires more observations. The ADF test statistics also have some defects because they have low power, and tend to under-reject the null of a unit root. Other tests for unit root, such as the Kwiatkowski-Phillips-Schmidt-Shin (KPSS) and Ng-Perron (NP) methods, are more powerful than the ADF, but also require more observations (Harris [24]).

\section{EMPIRICAL RESULTS}

\subsection{Empirical Analysis}

Li et al. [31] state that nonparametric statistical techniques can reveal structure in data that might be missed by common parametric functional specifications. The Kernel regression fit is a nonparametric regression method that fits local polynomials. The performance of Kernel estimation has been insensitive to the choice of Kernel function; however, the choice of bandwidth can generate different distributions, and therefore the variables have to be smoothed in an appropriate manner. Using a default bandwidth selection does not always provide good results due to the presence of outliers. The regression type is a local-constant, and the least squares cross-validation method is used to select the smoothing parameter (bandwidth). This method is based on selecting a bandwidth that minimises the integrated squared error of the resulting estimate; thus it provides an optimal bandwidth tailored to tax (x-axis) in support of growth ( $\mathrm{y}$-axis).

To compute the bandwidth, the $\mathrm{R}$ statistical software [43] with the Nonparametric Regression Bandwidth Selection package is used. The bandwidth type is fixed but the local observations are weighted according to a Kernel function ${ }^{5}$. The calculated bandwidth of 0.008545644 is then used in the estimation of the Kernel function. The $R$ square of 0.3862368 suggests that growth can explain $39 \%$ of the variation in tax.

In Figure 4 the Kernel fit displays the local polynomial Kernel regression fit of the rate of economic growth on the $y$-axis, and on the $x$-axis the $\tau=\frac{g}{g d p}$ ratio. The individual points

\footnotetext{
${ }^{4}$ The Johansen estimating technique indicates at most one cointegration equation at a 0.05 level of significance.

${ }^{5}$ Hayfield et al.[25]
} 
represent annual observations of these two variables for the period 1961 to 2007 . The profile of a Laffer curve can be observed in the inverted $U$ through the data points in the graph. It is clear that most of the tax ratios over the period lie to the right hand side of the optimum turning point of the curve. In fact, from the $19 \%$ margin up to the $22 \%$ margin the graph portrays characteristics of exponential decline in economic growth.

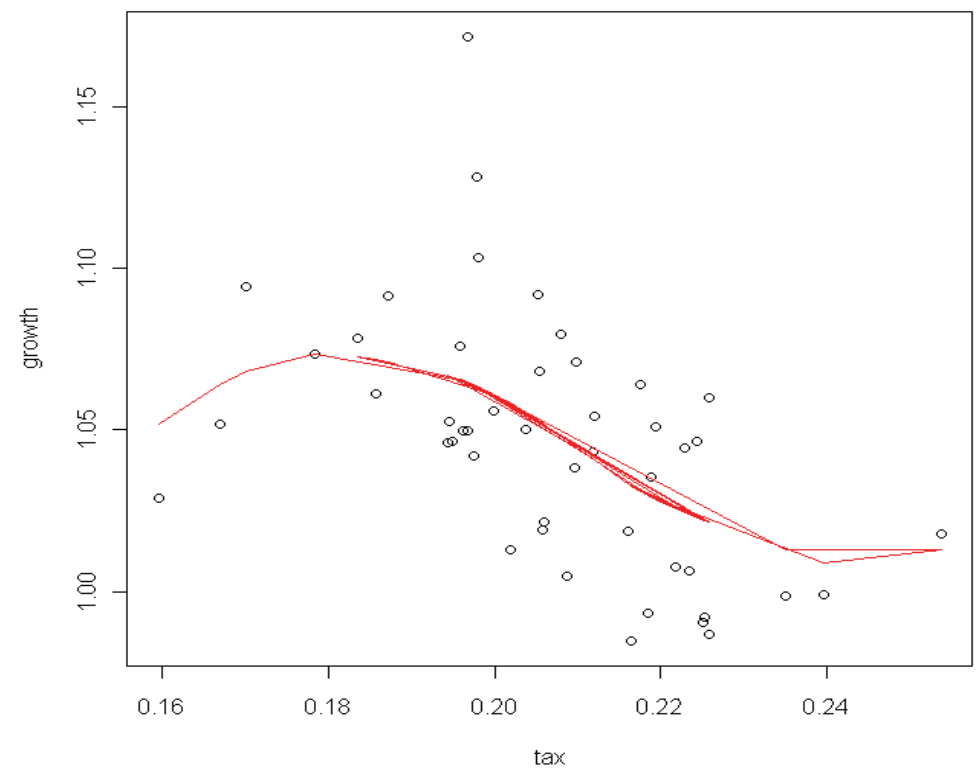

Figure 4: The tax ratio and economic growth rate in South Africa:

Scatter of annual observations

Source: R Statistical Software [43]

In Figure 5 the gradient component of growth is plotted against tax. The gradients are a generic function that extracts gradients from the regression function. The graph clearly shows that when the tax rate is less than $18 \%$ it has a positive impact on growth, while when the tax rate is more than $18 \%$ it has a negative impact on growth.

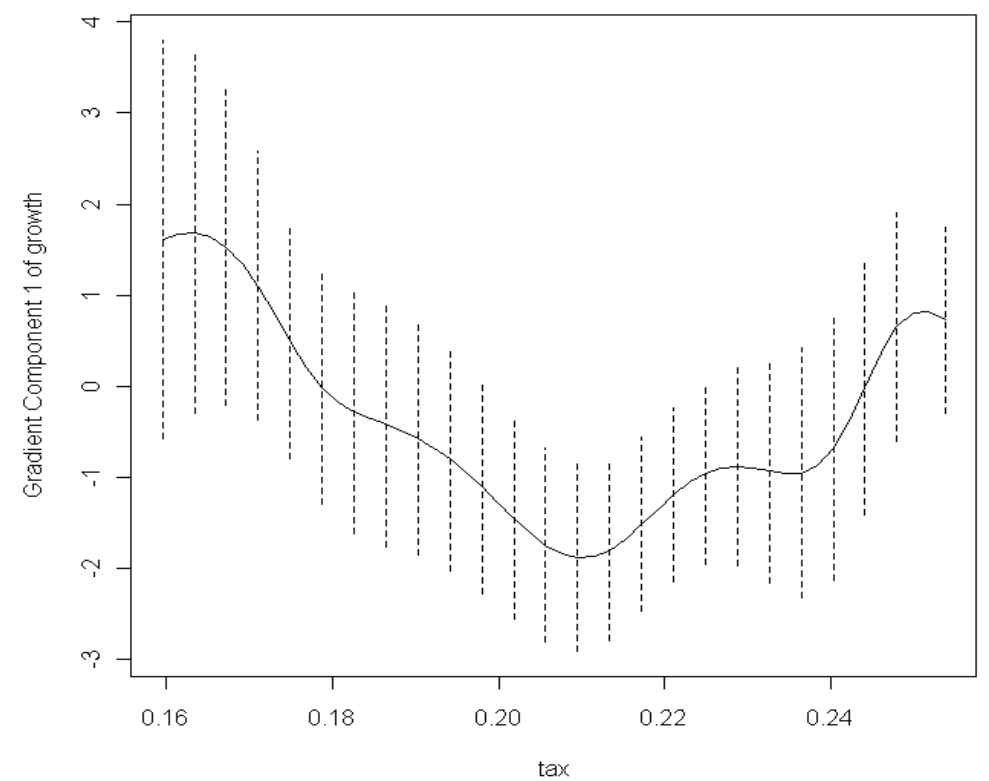

Figure 5: The gradient component of growth and tax in South Africa Source: R Statistical Software [43] 


\subsection{Production function for the South African economy}

The empirical production function for the South African economy used in this study is as follows:

$\operatorname{rgdp}=\stackrel{+}{f(r g, r n g})$

An increase in government and non-government input was expected to lead to an increase in output. Constant returns to scale were enforced, and the long-term equation was estimated as follows:

$\ln (\operatorname{rgdp})=c+\beta \ln \left(\mathrm{rg}_{t}\right)+(1-\beta) \ln \left(\mathrm{rng}_{\mathrm{t}}\right)$

The long-term results are as follows:

\begin{tabular}{|l|r|r|}
\hline \multicolumn{2}{|l|}{ Dependent variable: Inrgdp } & \\
\hline Variables & Coefficient & t-statistic \\
\hline Inrg & 0.18037 & 3.76877 \\
\hline Inrng & 0.79529 & 15.25371 \\
\hline C & 0.79691 & 5.13245 \\
\hline Adjusted R2 & 0.99664 & \\
\hline
\end{tabular}

Table 3: Output coefficients for the long-term cointegration equation Source: Own calculations

The signs and magnitudes of the variables in the long-term equation do conform to a priori expectations. It is expected that an increase in real government expenditure (lnrg) will increase economic growth until it reaches a maximum optimum point. Beyond that point, growth is lowered at a diminishing ratio.

An increase in real non-government expenditure (lnrgdp) will have a positive impact on economic growth because of increased expenditure. A one percent increase in real government expenditure would lead to a 0.18 percent increase in economic growth, and a one percent increase in real non-government expenditure tax would lead to a 0.80 percent increase in economic growth.

The residuals from this regression were tested for stationarity as follows:

Ho : no cointegration

$\mathrm{H}_{1}$ : cointegration

\begin{tabular}{|l|l|c|c|}
\hline Series & Model & Lags & $\tau$ \\
\hline res_l $r_{t-1}$ & Constant, no trend & 0 & -3.58961 \\
\hline
\end{tabular}

Table 4: Testing stationarity of the cointegrating residuals Source: Own calculations

The variables are cointegrated at a $10 \%$ level of significance, as -3.5896 is smaller than the calculated MacKinnon [33] critical value of -3.5859 , thereby rejecting the null hypothesis at a ten percent level of significance, indicating cointegration. The present of cointegration made it possible to estimate the error correction model (ECM) in the next step. 
The error correction model incorporating the short-run effects on economic growth corrects the stochastic residuals from the long-term cointegrating regression. The results are shown in Table 5, where (ln) preceding a variable indicates natural logs, and $\Delta$ indicates a first difference.

\begin{tabular}{|l|c|r|r|r|}
\hline \multicolumn{5}{|l|}{ Dependent variable: $\Delta$ lnrgdp } \\
\hline Variable & Coefficient & Standard Error & t-Statistic & p-Value \\
\hline res_lr $r_{\mathrm{t}-1}$ & -0.57418 & 0.12091 & -4.74856 & 0.0000 \\
\hline$\Delta$ lnrg & 0.22891 & 0.08163 & 2.80415 & 0.0076 \\
\hline$\Delta$ lnrng & 0.55174 & 0.07876 & 7.00503 & 0.0000 \\
\hline$\Delta$ lnrgdp $(-1)$ & 0.26972 & 0.10142 & 2.65939 & 0.0110 \\
\hline $\mathrm{R}^{2}=0.62844$ & & & \\
\hline Adjusted $\mathrm{R}^{2}=0.60190$ & & & \\
\hline S.E. of regression $=0.02317$ & & & \\
\hline
\end{tabular}

Table 5: Regression output of the Error Correction Model for rgdp Source: Own calculations

All the variables included in the ECM were originally I(1). Differencing them once transformed them into I(0) series. The lagged error correction coefficient is negative and statistically different from zero to support the existence of cointegration. It shows that $57 \%$ of disequilibrium was corrected for every year. The Adjusted R squared value indicates that $60.2 \%$ of the variation in growth is explained by the ECM.

All the diagnostic tests were performed on the ECM, with the following results:

\begin{tabular}{|l|l|l|c|l|}
\hline Layout & Test & Test statistic & $\mathrm{p}$-value & Conclusion \\
\hline Normality & Jarque Bera & $\mathrm{JB}=0.39$ & 0.82 & Normally distributed \\
\hline Serial Correlation & Ljung-Box $\mathrm{Q}$ & $\mathrm{LB}_{\mathrm{Q}}=16.90$ & 0.33 & No serial correlation \\
\hline & Breusch-Godfrey & $\mathrm{nR}^{2}=0.21$ & 0.65 & No serial correlation \\
\hline Heteroscedasticity & ARCH LM & $\mathrm{nR}^{2}=0.08$ & 0.77 & No heteroscedasticity \\
\hline & White (no cross) & $\mathrm{nR}^{2}=0.67$ & 0.95 & No heteroscedasticity \\
\hline Specification & Ramsey RESET & $\mathrm{LR}=0.23$ & 0.63 & Indicative of stability \\
\hline
\end{tabular}

Table 6: Selected diagnostic results of the short-term model estimating growth Source: EViews 6 [20]

With the diagnostic results at a $5 \%$ level of significance, all tests performed were significant. Therefore it seems reasonable to conclude that the residuals do satisfy the assumptions of the classical normal linear regression model.

\subsection{Optimum tax ratio that maximises growth}

The coefficients of the model are now used to calculate the optimal growth maximising tax ratio by solving equation (14): 


$$
\begin{aligned}
& \tau^{*}=\frac{\beta}{\beta+\delta} \\
& =\frac{0.180373}{0.180373+0.795298}{ }^{*} 100 \\
& =18.5 \%
\end{aligned}
$$

According to the model, the optimum $\frac{\text { tax }}{\text { gdp }}$ ratio for South Africa is $18.5 \%$. The actual level of tax as a share of GDP for 2006 was 26\%; in 2007 it increased to close to $28 \%$. Thus the tax ratio that maximises growth is substantially lower than the current realised rate. The optimum rate calculated is consistent with the findings of Scully [49], with rates between $19 \%$ and $23 \%$ for the United States and New Zealand.

It is also consistent with the findings of Mavrov [36] in Bulgaria, with an optimum ratio of $21.4 \%$ for government expenditure as a percentage of GDP. The growth maximising tax ratio of $18.5 \%$ might appear to be on the low side if measured against the revenue required to finance the government's budget. However, the challenge lies in fuelling economic growth that automatically inflates the tax base. So such a decline in the $\frac{\text { revenue }}{\text { gdp }}$ ratio might not be too far-fetched.

\section{CONCLUSIONS AND RECOMMENDATIONS}

In view of the skewed distribution of wealth in South Africa and its general levels of poverty, it is vital that government (among others) provide the nation with public goods such as infrastructure, health, education, and national security. However, such expenditure has to be financed from a limited (and skewed) tax base, with the result that - despite the merit of such expenditure - it becomes cost ineffective from a production point of view. The reason for this is that scarce resources are channeled away from the more productive private sector, so that economies of scale of government endeavours turn negative.

This paper finds that (in a balanced budget scenario) the optimum level of government intervention as represented by the ( $\left.\frac{\text { revenue }}{\text { gdp }}\right)$ ratio is approximately $18.5 \%$. This is in line with similar benchmarks for other countries reported in the literature, but much lower than the actual figures recorded over the past two decades. This indicates that the current average tax ratio for South Africa might be on the downward sloping portion of the Laffer curve. The tax burden, therefore, has a negative impact on economic growth. As part of tax reform, policy makers should consider the adjustment of tax rates to return to their optimum level, which in the case of South Africa would amount to an average 19\% (should borrowing not be an option).

\section{REFERENCES}

[1] Aaron, H.J. and Slemrod, J. 1999. The South African tax system: A nation in microcosm. Brookings. Tax Notes, The Brookings Institute: www.brook.edu.

[2] Abel, A.B. and Bernanke, B.S. 2005. Macroeconomics, $5^{\text {th }}$ edition, Pearson Education.

[3] Agbeyegbe, T., Stotsky, J.G. and Wolde, M.A. 2004. Trade liberalization, exchange rate changes and tax revenue in Sub-Saharan Africa, International Monetary Fund IMF Working paper. 
[4] Barro, R.J. 1990. Government spending in a simple model of endogenous growth, Journal of Political Economy, 98, pp 103-125.

[5] Barro, R.J. and Sala-I-Martin, X. 1992. Public finance in models of economic growth, The Review of Economic Studies, 59, pp 645-661.

[6] Bergoeing, R., Kehoe, T. J. and Soto. R. 2002. A decade lost and found: Mexico and Chile in the 1980s, Review of Economic Dynamics, 5, pp 166-205.

[7] Black, P.A., Calitz, E., and Steenkamp, T.J. 2006. Public economics for South African students, $2^{\text {nd }}$ edition, Oxford University Press.

[8] Boadway, R., Bruce, N. and Mintz, J. 1984. Taxation, inflation and the effective marginal tax rate on capital in Canada, The Canadian Journal of Economics, 17(1), pp 62-79.

[9] Brue, S.L. 2000. The evolution of economic thought, $6^{\text {th }}$ edition, Thompson South West.

[10] Budget Review. 2008. Pretoria, Department of Finance.

[11] Budget Review. 2007. Pretoria, Department of Finance.

[12] Budget Review. 2006. Pretoria, Department of Finance.

[13] Budget Review. 2002. Pretoria, Department of Finance.

[14] Caragata, P.J. 1998. From welfare state to optimal size of government: A paradigm shift for public policy, Agenda, 5(3), pp 277-287.

[15] Chao, J.C.P. and Grubel, H. 1998. Optimal levels of spending and taxation in Canada. How to use the fiscal surplus. Vancouver: Fraser Institute.

[16] Clemens, J. and Veldhuis, N. 2002. Size of government. Studies in economic prosperity 1 . Vancouver: The Fraser Institute.

[17] Devarajan, S., Swaroop, V. and Zou, H. 1996. The composition of public expenditure and economic growth. Research Department, The World Bank, Washington, DC 20433, USA.

[18] Dickey, D.A. and Fuller, W.A. 1981. Likelihood ratio statistics for autoregressive time series with a unit root, Econometrica, 49(4), pp 1057-1072.

[19] Engle, R.F. and Granger C.W.J. 1987. Co-integration and error correction: Representation, estimation, and testing, Econometrica, 55(2), pp 251-276.

[20] EViews 6 User's Guide II. 2007. United States of America: Quantitative Micro Software, LLC.

[21] Fan, J. and Marron, J.S. 1994. Fast implementations of nonparametric curve estimators, Journal of Computational and Graphical Statistic, 3(1), pp 35-56.

[22] Fatas, A. and Mihiv, I. 2000. Government size and automatic stabilizers: International and intranational evidence, Journal of International Economics, 55, pp 3-28.

[23] Feldstein, M. 2006. The effect of taxes on efficiency and growth, National Bureau of Economic Research Working Paper No. 12201. 
[24] Harris, R.I.D. 1995. Using cointegration analysis in econometric modelling, Prentice Hall.

[25] Hayfield, T. and Racine J.S. 2008. Nonparametric econometrics: The np package, Journal of Statistical Software, 27(5), URL http://jstatsoft.org/v27/i05/.

[26] Hood, R., Husband, D. and Yu, F. 2002. Recurrent expenditure requirements of capital projects: Estimation for budget purposes, The World Bank. Policy Research Working Paper No. WPS2938.

[27] Katz Commission. 1999. Interim reports of the Katz Commission into certain aspects of the tax structure of South Africa, Government Printer, Pretoria.

[28] Kennedy, P.E. 2000. On measuring the growth-maximizing tax rate, Pacific Review, 5(1), pp 89-91.

[29] Koch, S. F., Schoeman, N.J. and Tonder, J.J. 2005. Economic growth and the structure of taxes in South Africa: 1960-2002. The South African Journal of Economics, 73(2), pp 190-210.

[30] Laffer, A. 2004. The Laffer curve: Past, present and future, Executive Summary Backgrounder.

[31] Li, Q. and Racine, J.S. 2007. Nonparametric econometrics, Princeton University Press, pp 26-29.

[32] Mackness, W. 1999. Fraser Institute study makes the case for smaller more efficient government, The Fraser Institute, The Fraser Forum Online.

[33] MacKinnon, J.G. 1991. Critical values for cointegration tests. In long run economic relationships, London, Oxford University Press, pp 267-276.

[34] Manual, T.A. 2002. The South African tax reform experience since 1994, Annual Conference of The International Bar Association. National Treasury, Communications and Media, Speeches.

[35] Margo Commision. 1987. Report of the Commission of Inquiry into the tax structure of the Republic of South (Chairman: C.S. Margo). RP34/1987, Pretoria: Government Printer.

[36] Mavrov, H. 2007. The size of government expenditure and the rate of economic growth in Bulgaria, Journal of Economic Alternatives, Issue 1EN/2007.

[37] Mirrlees, J.A. 1971. An exploration in the theory of optimum income taxation, Review of Economic Studies, Blackwell Publishing, 38 (April), pp 175-208.

[38] Mitchell, D.J. 1996. How to measure the revenue impact of changes in tax rates. The Heritage Foundation. Backgrounder number 1090.

[39] Mitchell, D.J. 2001. Lowering marginal tax rates: The key to pro-growth tax relief. The Heritage Foundation, Backgrounder number 1443.

[40] OECD. 2003. African economic outlook, African Economic Outlook Report.

[41] Pevcin, P. 2004. Does optimal size of government spending exist?, University of Ljubljana, European Group of Public Administration, Study Group on Public Finance and Management. 
[42] Peden, E.A. and Bradley, M.D. 1989. Government size, productivity, and economic growth: The post-war experience, Public Choice 61, pp 229-245.

[43] R Development Core Team. 2008. R: A language and environment for statistical computing, R Foundation for Statistical Computing, Vienna, Austria, ISBN 3-90005107-0, URL http://www.R-project.org.

[44] Rosen, H.S. 2005. Public finance, $7^{\text {th }}$ edition, McGraw-Hill International.

[45] SARB (South African Reserve Bank). Various issues of the Quarterly Bulletin, Pretoria.

[46] Schoeman, N.J. 1995. Public debt and the economy, South African Journal of Economic and Management Sciences, 16 (Winter), pp 65-69.

[47] Scully, G.W. 1991. Tax rates, tax revenues and economic growth. Policy Report 98. Dallas, TX: National Centre for Policy Analysis.

[48] Scully, G.W. 1996. Taxation and economic growth in New Zealand, Pacific Economic Review, 1(2), pp 169-177.

[49] Scully, G.W. 2000. The growth-maximising tax rate, Pacific Economic Review, 5 (February), pp 93-96.

[50] Scully, G.W. 2002. Government expenditure and quality of life. Public Choice, 108, pp 123-145.

[51] Scully, G.W. 2003. Optimal taxation, economic growth and income inequality, Public Choice, 115, pp 299-312.

[52] Vedder, R.K. and Gallaway, L. 1998. Government size and economic growth, Washington: Joint Economic Committee.

[53] World Bank. 2007. World Development Report.

[54] Wing, Y. 2005. Government size and economic growth: Time-series evidence for the United Kingdom, Econometrics Working Paper: EWP0501. 